\title{
DONATED HUMAN TISSUE: IS IT A MEDICAL DEVICE OR JUST TISSUE?*
}

\author{
M Slabbert \\ $B A$ (Hons) HED BProc LLB LLD \\ Professor of Law, University of South Africa
}

\begin{abstract}
SUMMARY
Donated human tissue can be used in various ways. Bone and skin received by an authorised Tissue Bank are preserved and processed in order to be used in transplantations later. The question arises whether these products derived from human tissue stays just human tissue or do they become medical devices. The importance of this distinction is mainly to determine which legislative framework applies. Neither the National Health Act nor the Medicines and Related Substances Act give guidance on how to classify products as medical devices or human tissue. A Draft Guidance from the United States of America is analysed as well as a Directive from the European Communities. It is recommended that South Africa should change its current laws to give clarity to Tissue Banks.
\end{abstract}

\section{$1 \quad$ INTRODUCTION}

Developments in biotechnology make it possible that human tissue can be used in many ways apart from only organ transplantations. ${ }^{1}$ Human tissue from cadavers can be stored and manipulated to be used at a later stage for therapeutic purposes. These developments have raised many legal questions. This article only focuses on the use of bone and skin of deceased donors by an authorised Tissue Bank. The process of donating human tissue is not elaborated on as it is expected of a Tissue Bank to follow the law in procuring human tissue in a legal manner. The problems that Tissue Banks experience concerning their end products are the main focus of the article.

The Tissue Bank receives bone and skin from donors after which it is processed to be transplanted, the question then arises: Are these products still human tissue and therefore regulated by the National Health Act 61 of $2003(\mathrm{NHA})$ and the regulations in terms thereof or are the products manipulated to such an extent that they become medical devices and should

\footnotetext{
The author would like to thank Ms C Ndhlovu (CTE) and Dr L N Ramoshebi (Bone SA) for their valuable inputs.

1 Organs (heart, lungs, pancreas, liver and kidneys) can only be transplanted from a deceased (usually brain dead) while the blood flow is still continuing. With human tissue this is not necessary and tissue can be harvested after death, in other words even after a person has been taken off all life-sustaining machines.
} 
therefore be regulated by the Medicines and Related Substances Act 101 of 1965 (MRSA), including the regulations in terms of this Act.

There are currently no prescribed guidelines in South Africa to determine when a product of bone or skin is still considered tissue or a medical device. It is therefore necessary to seek guidance from abroad. The United States of America (US) is regarded as the country with the most comprehensive regulatory approach towards human tissue intended for transplantation and therefore its position will be scrutinized in detail. ${ }^{2}$ The US published in December 2014 a document for comments: the Draft Guidance for Industry and Food and Drug Administration Staff regarding the minimal manipulation of human cells, tissues and cellular- and tissue-based products. This draft document gives guidance on the minimal or more-than-minimal manipulation of human tissue. If tissue is more than minimally manipulated it becomes a medical device. The American document is juxtaposed against legislation in South Africa to indicate possible shortcomings. If the American guidelines are applied on South African human tissue products it could be an indication whether the end product of a Tissue Bank is still human tissue or whether it became a medical device. A table is used to clarify the position. Cognisance is also taken of the Council of European Communities' Directive 93/42/EEC of 14 June 1993 which resembles the definition of a medical device in the MRSA.

The importance of the classification of human tissue as either just tissue or a medical device is important to determine what legislation is applicable and should be complied with in South Africa. In conclusion recommendations are made to amend the current regulations to the NHA and the MRSA in order to clarify the uncertain position in South Africa.

\section{HUMAN TISSUE IN THE UNITED STATES OF AMERICA}

\section{The Food and Drug Administration}

In the US, the Food and Drug Administration (FDA) is the federal agency responsible for the regulation of human cellular and tissue-based products. ${ }^{3}$ The FDA was established in 2001. Since then there was an enormous growth in the human tissue products industry. Human tissue in the US is defined as:

"Any tissue derived from a human body, which (1) [is] intended for transplantation to another human for the diagnosis, cure, mitigation, treatment, or prevention of any condition or disease; (2) [i]s recovered, processed, stored or distributed by methods that do not change tissue function or characteristics; (3) [is] not currently regulated as a human drug, biological product, or medical device; (4) [e]xcludes kidney, liver, heart, lung,

2 Indech "The international harmonization of human tissue regulation: regulatory control over human tissue use and tissue banking in select countries and the current state of international harmonization efforts" 2000 Food and Drug Law Journal 55 347. For the position in Belgium, France, the United Kingdom and the European Union, see 352-366.

3 Indech 2000 Food and Drug Law Journal 55346. 
pancreas, or any other vascularized human organ, and (5) [e]xcludes semen or other reproductive tissue, human milk, and bone marrow."

The FDA derives its regulatory authority over human tissue from the Public Health Service Act. ${ }^{5}$ Since the start of the FDA some human cells, tissues and cell- and tissue-based products (HCT/P's) were subjected only to the regulation under section 361 of the Public Health Service Act (PHSA). These "section $361 \mathrm{HCT} / \mathrm{P}$ 's" did not require premarket approval if the products were minimally manipulated. Other HCT/P's that were more than minimally manipulated, not used for homologous purposes ${ }^{6}$ or were dependent on metabolic activity were regulated under section 351 of the PHSA and did require FDA premarket approval in the form of a Biologics Licence Application (BLA). Examples of HCT/P's include but are not limited to: bone, ligaments, skin, dura mater, heart valves, corneas, hematopoietic stem/progenitor cells derived from peripheral and cord blood, manipulated chondrocytes, epithelial cells on a synthetic matrix and semen or other reproductive tissue. ${ }^{7}$

The US's ${ }^{8}$ Minimal Manipulation of Human Cells, Tissues, and Cellular and Tissue-based Products Draft Guidance for Industry and Food and Drug Administration Staff was published in December 2014. ${ }^{9}$ This Draft Guidance addresses the criterion under Title 21 of the Code of Federal Regulations (CFR) Part 1271, specifically the 21 CFR $1271.10(a)(1)$ criterion of minimal manipulation. It is anticipated that this guidance will improve stakeholders' understanding of the definitions of minimal manipulation and how to apply such definitions to their HCT/P's.

Section 1271.10(a)(1) provides that one of the criteria for an HCT/P to be regulated solely under section 361 of the PHSA and 21 CFR Part 1271 is that the HCT/P is minimally manipulated. Criteria for a HCT/P to be regulated solely under section 361 of the PHSA are thus:

- minimal manipulation;

- intended for homologous use only, as reflected in the labelling, advertising, or other indications of the manufacturer's objective intent;

- not combined with a drug or device, except for water, crystalloids, or a sterilizing, preserving or storage agent provided that the addition of the

\footnotetext{
Indech 2000 Food and Drug Law Journal 55346.

42 U.S.C § 264 (1994).

6 "Homologous use" means similarity of position and structure in other words it means the repair, reconstruction, replacement, or supplementation of a recipient's tissues with an $\mathrm{HCT} / \mathrm{P}$ that performs the same basic functions in the recipients as in the donor.

7 United States of America "Minimal Manipulation of Human Cells, Tissues, and Cellular and Tissue-based Products Draft Guidance for Industry and Food and Drug Administration" 20142 fn 2.

8 U.S. Department of Health and Human Services, Food and Drug Administration (FDA), Center for Biologics Evaluation and Research (CBER), Center for Devices and Radiological Health $(\mathrm{CDRH})$ and the Office of Combination Products in the Office of the Commissioner (OCP).

9 When finalized, this Guidance will supersede the 2006 Guidance.
} 
water, crystalloids, or sterilizing, preserving agent does not raise new clinical safety concerns with respect to the HCT/P;

- not have a systematic effect and not depend on the metabolic activity of living cells for its primary function except if for autologous use, allogeneic use in a first-degree or second degree blood relative, or reproductive use.

As defined in 21 CFR 1271.3(f), minimal manipulation means:

“(1) For structural tissue, minimal manipulation means that the processing of the HCT/P does not alter the original relevant characteristics of the tissue to the tissue's utility for reconstruction, repair, or replacement (21 CFR 1271.3(f)(1)).

(2) For cells or non-structural tissues, minimal manipulation means that the processing of the HCT/P does not alter the relevant biological characteristics of cells or tissues (21 CFR 1271.3(f)(2))."

The main function of the HCT/P in the donor determines which definition of minimal manipulation applies. Tissues that physically support or serve as a barrier or conduit or connect, cover or cushion are generally considered structural tissues. Bone supports the body and protects internal structures, such as the brain, and skin provides a barrier to retain moisture and protects a body against infections, both bone and skin are therefore considered structural tissue. ${ }^{11}$ Processing of HCT/P's can change the tissue from minimally manipulated to more than minimally manipulated. Processing means testing for microorganisms, preparation, sterilization, steps to inactivate or remove adventitious agents, preservation for storage and removal from storage. ${ }^{12}$ It further includes cutting, grinding, shaping, culturing, enzymatic digestion and decellularisation. To determine whether the process changed the HCT/P from minimal manipulation to more than minimal manipulation consideration should be had as to whether the original relevant characteristics of the tissue, relating to the tissue's utility for reconstruction, repair, or replace, as structural tissue have been changed. A tissue's characteristic is "original" if it is present in the tissue of the donor and this originality is relevant if it could have a meaningful bearing on the tissue's utility for reconstruction, repair or replacement. ${ }^{13}$ Separation of structural tissue into components in which the relevant characteristics relating to reconstruction, repair or replacement are not altered generally would be considered merely as minimal manipulation. What are important are thus the effects the processing has on the properties that contribute to the specific tissue's functioning in the donor. Each type of tissue that is manufactured should be evaluated against this criterion when determining whether the product was minimally manipulated or not. ${ }^{14}$

In other words whether mechanical methods of processing or chemical modification are used, the same question needs to be answered in order to determine whether it was minimally manipulated or not. Did the method of modification alter the HCT/P's physical state relating to its utility (in the

\footnotetext{
US Draft Guidance 2

US Draft Guidance 5.

US Draft Guidance 4

US Draft Guidance 5

Ibid.
} 
donor) for reconstruction, repair, or replacement? The following example given might clarify the position or complicate it: The original relevant characteristics of cartilage to perform its loadbearing and other physical functions generally include firmness, smoothness, and flexibility. A cartilage allograft that is homogenised (changed from a solid to a slurry or gel) generally is considered more than minimally manipulated because the processing alters the utility of the HCT/P to absorb shock and reduce friction between joints as it would have done in the body of the donor, yet, it stays cartilage whether present as solid or a gel. ${ }^{15}$

The Draft Guidelines, although not without uncertainties, are useful for determining whether a product is still just human tissue or if it has become a medical device. This is still a "draft" document but it is proposed that the suggested method in the guidelines should be adapted and used in South Africa to determine whether donated tissue stay tissue or become a medical device, as neither the NHA nor the MRSA is clear on how to determine which category processed tissue falls into.

\section{Criticism against the Draft Guidance of 2014}

Since the publication of the Draft Guidance the FDA has received numerous comments from role players in the industry. The FDA therefore decided to have a public meeting on 13 April 2016 to discuss the issues relating to the Draft Guidelines. ${ }^{16}$ Five notices announcing the developments were published in October 2015. Shortly after the publication the stock market value of distributors of human tissue fell. It was argued that this was as a direct result of the confusion in the field, for example the qualification that human tissue (and not a medical device) should be intended for homologous use. The Draft Guidance stipulates that amniotic membrane is used for bone tissue replacement to support bone regeneration following surgery to repair or replace bone defects and according to the guidelines this is not a homologous use as bone regeneration is not a basic function of amniotic membrane. ${ }^{17}$ The reaction to this was that that the concept of homologous use is misunderstood and this element actually only relates to the marketing of the product which could be corrected with the appropriate labelling. In other words the labelling and packaging of the products is also very important as it may change a product from a tissue to a medical device. If a ligament is packaged with gauze it no longer stays tissue but becomes a medical device as a "device" is added to the tissue. In order to avoid this, packaging should clearly state that the ligament is tissue and the gauze is a protection device in order to prevent confusion.

AlloSource, a non-profit organisation in the US, commented on the draft guidance that the result of minimal manipulation controls will drive many currently available and economical human bone products into being classified as medical devices. This will result in bone products being

US Draft Guidance 7-8.

16 Aquino "FDA Issues Draft Cells, Tissues, Rattles Stocks" 2016 http://www.bna.com/fdaissues-draft-n57982063007/ (accessed 2016-04-20).

17 Ibid. 
subjected to unnecessary rules and regulations and unwarranted clinical studies which will greatly reduce the availability of these products, as well as drive the prices higher than the current synthetic or metal equivalent medical devices. ${ }^{18}$ This according to AlloSource is not needed in light of the history of the various uses of human bone in the repair of injured or deceased bone in patients. The organisation also complained about the requirement of "homologous use" only. According to them the homologous use restriction will result in tissue banks having huge inventories of unused donated human allografts. The subsequent destruction of donated bone is a violation of the basic premise behind human bone allograft donation, that being the donated bone will be used in some application for a living patient in need. They therefore strongly recommend that donated human bone allografts remain as human tissue and should not be classified as medical devices. "AlloSource can see no logical or medical rationale for the enactment of such restrictions as minimal manipulation and homologous use."19 Despite the comments raised by some, the US at least has something on the table to work from. In South Africa the only direction given to Tissue Banks is to analyse current legislation and the regulations thereto.

\section{HUMAN TISSUE IN SOUTH AFRICA}

\section{The National Health Act 61 of 2003}

The NHA provides "a framework for a structured uniform health system within the Republic ..." ${ }^{\prime 20}$ In Section 1 of the Act it is stated that "this Act" includes any regulation made thereunder. "[T]issue is defined as meaning human tissue, including flesh, bone, a gland, an organ, skin, bone marrow or body fluid, but excludes blood or a gamete." Chapter 8 of the Act addresses the control of use of blood, blood products, tissue and gametes in humans.

Section 54 stipulates that a ministerial authorised institution may acquire, use and supply any tissue removed from a deceased person. ${ }^{21}$ Thus a Tissue Bank complying with the authorisation process may acquire, use and

18 AlloSource "Position paper on human bone allograft; minimal manipulation and homologous use" http://www. allosource.org (accessed 2016-04-20).

9 Ibid.

20 The long title of the Act.

21 Sec 54 Designation of authorised institution

"(1) The Minister may, by notice in the Gazette, designate any institution other than an institution contemplated in section 63 as an authorised institution

(2) An authorised institution may -

(a) acquire, use or supply the body of a deceased person for any purposes referred to in section 64 ;

(b) acquire or use any tissue lawfully imported or removed from the body of a living or deceased person for any of the purposes referred to in section 56 or 64 , as the case may be;

(c) supply any tissue preserved by it to an institution or person contemplated in section 63 for any of the purposes referred to in section 58 or 64 ; and

(d) acquire, use and supply blood products for any of the purposes referred to in section 56 or 64 .

(3) The Minister may, in the notice contemplated in subsection (1), impose conditions in respect of the exercise of a power referred to in subsection (2)." 
supply tissue they received legally from donors. Section 60 determines that an institution, like a Tissue Bank, may charge an amount for the human tissue products they provide as long as the amount is reasonable to cover the costs involved with the acquisition or supply of the tissue, but it is an offence to trade in tissue, meaning using donated tissue for products to be sold for profit. ${ }^{22}$ Most Tissue Banks are non-profit companies (NPC's) and are therefore within the legislative framework.

Section 64 addresses the purpose of tissue donations which, amongst others, are for therapeutic purposes including the use of tissue in any living person; or the production of a therapeutic, diagnostic or prophylactic substance. Tissue Banks specifically provide tissue for transplantation and thus the tissue is for therapeutic use and within the legislative requirement. ${ }^{23}$ Section 68 confirms the right of the Minister to make regulations concerning the removal of donated tissue, tissue transplants, the production, packaging, sealing, labelling, storage and supplying of therapeutic, diagnostic and prophylactic substances from tissue including the manipulation thereof.

Section 68 of the Act thus authorised the Minister to publish the Regulations Relating to Tissue Banks of 2 March 2012. ${ }^{24}$ The Regulations define "altered form" as human tissue that has been adapted, changed or transformed from its original form as donated by a person, to a form that is more suitable for transplantation into another person. No mention is made of minimal or more than minimal manipulation. "Processing" is described as all procedures involved in the preparation, manipulation, preservation and packaging of tissues intended for human applications. Once again, although the word manipulation is used, there is no indication of minimal or otherwise manipulation of the tissue. The rest of the regulations address the use of

22 Sec 60 Payment in connection with the importation, acquisition or supply of tissue, blood, blood products or gametes

"No person, except -

(a) a hospital or an institution contemplated in section 58(1)(a);and a person or an institution contemplated in section 63 and an authorised institution or, in the case of tissue or gametes imported or exported in the manner provided for in the regulations, the importer or exporter concerned, may receive payment in respect of the acquisition, supply, importation or export of any tissue or gamete for or to another person for any of the purposes contemplated in section 56 or 64 ;

(b) $\ldots$ blood ...

(1) The amount of payment contemplated in subsection (1) may not exceed an amount which is reasonably required to cover the costs involved in the importation, export, acquisition or supply of the tissue, gamete, blood or blood product in question.

(2) Remuneration of....

(3) It is an offence for a person -

(a) who has donated tissue, a gamete, blood or a blood product to receive any form of financial or other reward for such donation, except for the reimbursement of reasonable costs incurred by him or her to provide such donation; and

(b) to sell or trade in tissue, gametes, blood or blood products, except as provided for in the Chapter.

23 "tissue bank" is defined in the Regulations as meaning an organization, institution or person that provides or engages in one or more services involving cells and/or tissue from living or deceased individuals for transplantation purposes and is registered in terms of regulation 3 of these regulations.

24 GG R182 No 35099 of 2 March 2012. 
human tissue, the authorisation of a Tissue Bank, the organisational structure of tissue banks, reporting obligations, duties of the health officer, inspection and control measures, confidentiality and research. Minimal or more than minimal manipulation of the human tissue is not addressed, which is a vacuum and as argued above could be filled by following the example of the draft US document.

Should the tests as discussed above from the US draft document be applied to South African human tissue products and it is found that they are more than minimally manipulated, it should be classified as a medical device and then the Medicines and Related Substances Act comes into play.

\section{Medicines and Related Substances Act 101 of 1965}

The intention of the MRSA is to provide for the registration of medicines intended for human or animal use, for the registration of medical devices, for the establishment of a Medicines Control Council, for the control of medicines, scheduled substances and medical devices and for matters incidental thereto. A "medical device" 25 is defined as:

"any instrument, apparatus, implement, machine, appliance, implant, reagent for in vitro use, software, material or other similar or related article, including Group III and IV Hazardous Substances contemplated in the Hazardous Substances Act,1973 (Act No. 15 of 1973) -

(a) Intended by the manufacturer to be used, alone or in combination, for human or animals, for one or more of the following:

(i) diagnosis, prevention, monitoring, treatment or alleviation of disease;

(ii) diagnosis, monitoring, treatment, alleviation of or compensation for an injury;

(iii) investigation, replacement, modification or support of the anatomy or of a physiological process;

(iv) supporting or sustaining life;

(v) control of conception;

(vi) disinfection of medical devices; or

(vii) providing information for medical or diagnostic purposes by means of in vitro examination of specimens derived from the human body; and

(b) which does not achieve its primary intended action by pharmacological, immunological or metabolic means, in or on the human or animal body, but which may be assisted in its intended function by such means."

In the above definition of a medical device there is no indication on how to determine when a product becomes a medical device. No explanation of minimal manipulation is provided. The definition, although extensive, serves no purpose in the classification of human tissue products.

The Medicines and Related Substances Amendment Act 14 of 2015 makes provision for the establishment of a South African Health Products Regulatory Authority which would replace the Medicines Control Council. "The objects of the Authority are to provide for the monitoring, evaluation, regulation, investigation, inspection, registration and control of ... medical devices, ... and related matters in the public interest." ${ }^{26}$ The Authority will act

25 As per the Medicines and Related Substances Amendment Act 14 of 2015 s 1(h) (MRSAA). 26 Inserted in the MRSA as s $2 A$. 
through its Board. ${ }^{27}$ The functions amongst others of the Authority are to ensure the efficient, effective and ethical evaluation or assessment and registration of ... medical devices ... that meet defined standards of quality, safety, efficacy and performance. ${ }^{28}$ This should be done in a transparent, fair and objective manner and concluded timeously. ${ }^{29}$ The Authority will also reevaluate medical devices from time to time and monitor or analyse adverse events. It will ensure compliance with existing legislation and it may liaise with other regulatory authorities on interests of common concern or a specific investigation. The Authority may also enter into agreements to cooperate with any regulatory authority in order to achieve the objectives of the Act. $^{30}$

The Chief Executive Officer of the Authority shall keep registers in which he/she shall record the registration of ... medical devices ..., this information shall also be published on the Authority's website. ${ }^{31}$ In other words the Amendment Act addresses medical devices quite extensively, yet, no indication is given in the original Act or in all the amendments on how to determine when is a product just human tissue and when it is a medical device. It seems as if it will be a function of the newly-established Authority to determine whether a product is in fact a medical device or just human tissue, but most importantly no indication is given what guidelines they will follow.

Section 35 of the Act (as amended) concerning regulations give the Minister the authority to make regulations amongst others providing for the classification of medicines, medical devices or IVDs into classes or categories for the purposes of this Act. ${ }^{32}$ On 14 July 2015 the General Regulations Relating to Medical Devices and In Vitro Diagnostic Medical Devices (IVD's) has been published by the Department of Health for comment. ${ }^{33}$ These regulations do not address the issue of determining when a product is a medical device or not. The regulations are mainly focused on international tendering, the importing of medical devices and the licensing of medical devices. It could therefore be suggested than a review of these regulations might also assist in the clarification of how to determine when a human bone or skin product is in fact a medical device or not.

\section{THE COUNCIL OF THE EUROPEAN COMMUNITIES}

The Council Directive 93/42/EEC of 14 June 1993 concerning medical devices defines a medical device as follows:

"2 For the purposes of this Directive, the following definitions shall apply:

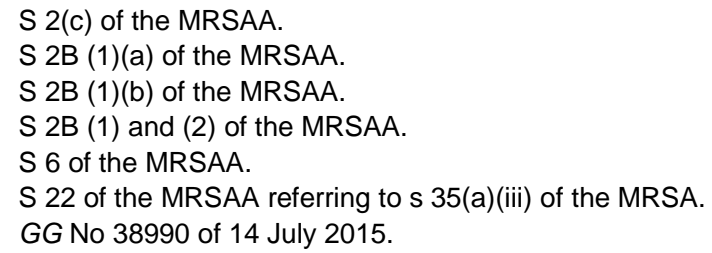


(a) 'medical device' means any instrument, apparatus, appliance, material or other article, whether used alone or in combination, including the software necessary for its proper application intended by the manufacturer to be used for human beings for the purpose of:

- diagnosis, prevention, monitoring, treatment or alleviation of disease,

- diagnosis, monitoring, treatment, alleviation of or compensation for an injury or handicap,

- investigation, replacement or modification of the anatomy or of a physiological process,

- control of conception

and which does not achieve its principal intended action in or on the human body by pharmacological, immunological or metabolic means, but which may be assisted in its function by such means; ..."

The South African definition resembles this European definition of 1993. The importance or difference is that the definition in the MRSA does not continue to add what the Directive did. In section 5 of the Directive is stated that the Directive does not apply to:

"(a) in vitro diagnostic services;

(b) active implantable devices covered by Directive 90/385/EEC;

(c) medicinal products covered by Directive 65165/EEC;

(d) cosmetic products covered by Directive 76/768/EEC;

(e) human blood, human blood products, human plasma or blood cells of human origin or to devices which incorporate at the time of placing on the market such blood products, plasma or cells;

(f) transplant or tissue or cells of human origin nor to products incorporating or derived from tissues or cells of human origin; (own emphasis)

(g) transplants or tissues or cells of animal origin, unless a device is manufactured utilizing animal tissue which is rendered non-viable or nonviable products derived from animal tissue."

This exclusion of products from human origin is significant and it is not clear why the MRSA does not have a similar indication. If it was part of the MRSA the position concerning skin and bone will be clear in that the products derived from it will never be medical devices but remain classified as human tissue.

\section{DISCUSSION AND RECOMMENDATIONS}

As indicated earlier, to determine whether an end-product from a Tissue Bank is a medical device or still human tissue is important as the classification indicates which legal framework applies. This is relevant as section 60 of the NHA, as pointed out above, determines that only the reasonable costs incurred with a donation and the supply of tissue products may be paid for and that the selling or trade in human tissue is forbidden. If the end-product of a Tissue Bank is therefore a medical device, such a Tissue Bank will not be guilty of an offence under the NHA if sold for profit, because the transaction and registration of the product will be regulated under the MRSA with different stipulations.

${ }^{34}$ See (b)-(i) in the Directive itself. 
Taking the South African legislative requirements into consideration and using the US' Draft Guidance, it is argued that the majority of bone and skin products distributed by an authorised Tissue Bank are minimally manipulated and therefore stay human tissue controlled by the NHA and the regulations in terms thereof. Tissue Banks that are changing human tissue into products to be sold on a "for profit" basis violates the NHA if the products they are selling stay human tissue, yet, if the products are labelled medical devices they are safe.

Before recommendations are made a table is included to indicate the change of some products at a Tissue Bank and a determination of whether the product is still just human tissue or whether it became a medical device according to the US Draft Guidance.

\section{TABLE 1}

\begin{tabular}{|c|c|c|c|c|}
\hline Donor & Process & Function & Packaging & Determination \\
\hline $\begin{array}{l}\text { Tissue } \\
\text { donated } \\
\text { and its } \\
\text { location in } \\
\text { the body }\end{array}$ & $\begin{array}{l}\text { Minimum } \\
\text { manipulation or } \\
\text { more than } \\
\text { minimum } \\
\text { manipulation }\end{array}$ & $\begin{array}{l}\text { Function in } \\
\text { donor and } \\
\text { function in } \\
\text { recipient }\end{array}$ & $\begin{array}{l}\text { With or } \\
\text { without a } \\
\text { medical } \\
\text { device } \\
\text { (MD) }\end{array}$ & $\begin{array}{l}\text { Is it a device or } \\
\text { tissue? }\end{array}$ \\
\hline $\begin{array}{l}\text { Cancellous } \\
\text { bone from } \\
\text { upper and } \\
\text { lower limbs }\end{array}$ & $\begin{array}{l}\text { Cleaning and } \\
\text { chemical defatting } \\
\& \text { dehydration. } \\
\text { Minimum } \\
\text { manipulation }\end{array}$ & $\begin{array}{l}\text { Homologous } \\
\text { use. Cortical } \\
\text { bone is used } \\
\text { to replace } \\
\text { missing } \\
\text { cortical } \\
\text { bone. }\end{array}$ & $\begin{array}{l}\text { Without } \\
\text { MD }\end{array}$ & Tissue \\
\hline $\begin{array}{l}\text { Cortical } \\
\text { bone from } \\
\text { upper and } \\
\text { lower limbs }\end{array}$ & $\begin{array}{l}\text { Cleaning and } \\
\text { chemical defatting } \\
\& \text { dehydration. } \\
\text { Minimum } \\
\text { manipulation }\end{array}$ & $\begin{array}{l}\text { Homologous } \\
\text { use. Cortical } \\
\text { bone is used } \\
\text { to replace } \\
\text { missing } \\
\text { cortical } \\
\text { bone. }\end{array}$ & $\begin{array}{l}\text { Without } \\
\text { MD }\end{array}$ & Tissue \\
\hline $\begin{array}{l}\text { Ligaments } \\
\text { from lower } \\
\text { limbs }\end{array}$ & $\begin{array}{l}\text { Cleaning and } \\
\text { chemical } \\
\text { disinfection. } \\
\text { Minimum } \\
\text { manipulation }\end{array}$ & $\begin{array}{l}\text { MD is only } \\
\text { used as part } \\
\text { of } \\
\text { packaging. } \\
\text { Does not } \\
\text { alter the } \\
\text { structure or } \\
\text { performance } \\
\text { of the } \\
\text { ligaments in } \\
\text { any way. }\end{array}$ & $\begin{array}{l}\text { With MD } \\
\text { (gauze) }\end{array}$ & Tissue \\
\hline $\begin{array}{l}\text { Cartilage } \\
\text { from chest }\end{array}$ & $\begin{array}{l}\text { Cleaning and } \\
\text { chemical } \\
\text { disinfection. } \\
\text { Minimum } \\
\text { manipulation }\end{array}$ & $\begin{array}{l}\text { Used to } \\
\text { repair or } \\
\text { replace } \\
\text { cartilage in } \\
\text { the nose and } \\
\text { ear. }\end{array}$ & $\begin{array}{l}\text { Without } \\
\text { MD }\end{array}$ & Tissue \\
\hline DBM & $\begin{array}{l}\text { Cortical cleaning. } \\
\text { Chemical } \\
\text { defatting \& } \\
\text { dehydration. } \\
\text { Demineralization. }\end{array}$ & $\begin{array}{l}\text { Used to } \\
\text { induce bone } \\
\text { formation }\end{array}$ & $\begin{array}{l}\text { Without } \\
\text { MD }\end{array}$ & Tissue \\
\hline
\end{tabular}




\begin{tabular}{|c|c|c|c|c|}
\hline Donor & Process & Function & Packaging & Determination \\
\hline $\begin{array}{l}\text { Tissue } \\
\text { donated } \\
\text { and its } \\
\text { location in } \\
\text { the body }\end{array}$ & $\begin{array}{l}\text { Minimum } \\
\text { manipulation or } \\
\text { more than } \\
\text { minimum } \\
\text { manipulation }\end{array}$ & $\begin{array}{l}\text { Function in } \\
\text { donor and } \\
\text { function in } \\
\text { recipient }\end{array}$ & $\begin{array}{l}\text { With or } \\
\text { without a } \\
\text { medical } \\
\text { device } \\
\text { (MD) }\end{array}$ & $\begin{array}{l}\text { Is it a device or } \\
\text { tissue? }\end{array}$ \\
\hline & $\begin{array}{l}\text { (more than } \\
\text { minimum } \\
\text { manipulation) }\end{array}$ & & & \\
\hline Collagen & $\begin{array}{l}\text { Cortical cleaning. } \\
\text { Chemical } \\
\text { defatting \& } \\
\text { dehydration. } \\
\text { Demineralization. } \\
\text { (more than } \\
\text { minimum } \\
\text { manipulation) }\end{array}$ & $\begin{array}{l}\text { Used to } \\
\text { induce bone } \\
\text { formation }\end{array}$ & $\begin{array}{l}\text { With MD } \\
\text { (syringe) }\end{array}$ & Tissue \\
\hline Skin & $\begin{array}{l}\text { Disinfection and } \\
\text { preservation } \\
\text { (minimum } \\
\text { manipulation) }\end{array}$ & $\begin{array}{l}\text { Used as } \\
\text { temporary } \\
\text { skin } \\
\text { supplement }\end{array}$ & $\begin{array}{l}\text { Without } \\
\text { MD }\end{array}$ & Tissue \\
\hline Cornea & Preservation & $\begin{array}{l}\text { To replace } \\
\text { damaged } \\
\text { corneas }\end{array}$ & $\begin{array}{l}\text { Without } \\
\text { MD }\end{array}$ & Tissue \\
\hline
\end{tabular}

The Guidance is not explicit in every circumstance and therefore if accepted in South Africa as a workable method of determining whether a product is a medical device or not, it should be adapted for South African use. It seems as if the European Directive is a simpler way of addressing the question. By just adding section 5(f) of the European Directive in the MRSA it would be clear that bone and skin remains tissue even after being manipulated minimally or more than minimally. Another alternative might be the amendment of the regulations concerning Tissue Banks ${ }^{35}$ to first of all define "human tissue" according to the US definition and then to also include a definition of minimal manipulation or to clearly state products derived from human origin remains tissue.

\section{CONCLUSION}

As indicated at the beginning of the article, technology has opened up a lot of new possibilities in the use of donated human tissue. Unfortunately legislation is not clear on how these new products derived from donated human tissue should be classified. This could become an issue in future as all Tissue Banks would like to comply with legal requirements but then it should be clear what legislation and regulations are in fact applicable. It has been argued that the use of the US draft guidelines might serve as a way forward, but it is in no way argued that it should be followed to the letter. By adding the part highlighted above of the European Directive seems to be a much faster and effective solution. Until such time as legislative clarity is given Tissue Banks will never be sure they are one hundred per cent compliant with all requirements.

35 Regulations Relating to Tissue Banks GG No R182 No 35099 of 2 March 2012. 